\title{
Regulation of Amylase-Glucose-Insulin via Dietary Supplemental of Zinc in Weanling Pigs
}

\author{
Ilakshy Deka ${ }^{1}$, B. C. Sarmah ${ }^{2}$, J. Goswami ${ }^{2}$, D. Kalita ${ }^{3}$ \\ ${ }^{1}$ Krishi Vigyan Kendra, Kaliapani, Teok, Jorhat, Assam Agricultural University, Jorhat, Assam, India \\ ${ }^{2}$ Department of Veterinary Physiology, College of Veterinary Science, Assam Agricultural University, Khanapara, Guwahati-22, Assam, \\ India \\ ${ }^{3}$ All India Coordinated Research Project on pig, College of Veterinary Science, Assam Agricultural University, Khanapara, Guwahati-22, \\ Assam, India
}

\begin{abstract}
The impact of supplemental Zinc on Amylase - Glucose - Insulin regulation were studied in 15 numbers of weanling pigs 87.50 percent Hampshire (Hampshire $X$ Meghalaya local) weaned at 60 days of age, apparently healthy with uniform body weight (10.60 to $10.70 \mathrm{~kg}$ ) were selected for the experiment and were randomly allocated into 3 treatment groups viz. Group $A(100 \mathrm{ppm} \mathrm{Zn}$ ) as per the recommendation of NRC (1998) which was considered as control, B (200ppm Zn) and C (300ppm Zn) comprising 5 weanling pigs in each group. The experiment was conducted for a period of 4 months (2 to 6 months of age). The body weight gain (BWG) was measured and serum sample were collected at fortnightly interval from 2 to 6 months of age. The BWG, serum zinc concentration, amylase activity and insulin concentration was found significantly $(P<0.01)$ higher in group $C$ followed by $B$ whereas the lowest was in group $A$ at the end of the experiment (6 month of age). Significantly $(P<0.01)$ highest serum glucose concentration was observed in $A$ group whereas, lowest was in $C$ group. The variations in response to dietary supplemental zinc among treatments could be related to the stimulation of Amylase - Glucose - insulin pathway by dietary zinc supplementation to enhance the body weight.
\end{abstract}

Keywords: Zinc, Glucose, Amylase, Insulin, Pig

\section{Introduction}

The multifaceted mineral's domine has impressed the scientists worldwide to go for investigation on its application prospects to boost up annual production. Minerals play an important role in metabolism of protein, fat and carbohydrate and are also important constituents of chromosome, enzymes, nerves, blood, skeleton, hair and milk etc. (Carlson and Boren, 2001). Zinc is one among the trace minerals which play significant roles in various physiological functions supporting life (Yousef, 2002) as it controls about 1000 metaloenzymes in the body (Pralluf, 2005). To accomplish the normal body functions, adequate level of dietary zinc is essential (Azizzadeh et. al., 2005; Chauhan et. al., 2006). The dietary requirement of zinc in porcine may be more due to the fact that, pig has the ability to grow faster, attain early puberty, produces larger litter size at a time with shorter inter-furrowing interval and give birth to larger number of offspring during the life time (Carlson and Boren, 2001). Many researchers (Heugten et. al., 2003; Martinez et. al.,2005; Kumar et. al.,2006) believed that the dietary requirement of zinc might be higher in pig than the NRC,1998 recommendation. North Easter region of India is no exception as its soil and water iron concentration is very high which one of the competitive antagonists of zinc is. This experiment was designed with the hypothesis that dietary supplementation of zinc higher than NRC recommendation could make more zinc available for various bodily functions along with it trigger the Amylase - Glucose - Insulin pathway to enhance the body weight. Thus the objective of this study were to determine the possible effects of dietary zinc on BWG, serum zinc, amylase, glucose and insulin in weanling pig.

\section{Material and Methods}

The research was conducted at the pig farm of the Division of Animal Production, ICAR Research Complex for North Eastern Hill Region, Umiam, Barapani, Meghalaya and in the Department of Veterinary Physiology, College of Veterinary Science, Assam Agricultural University, Khanapara, Guwahati -781 022, Assam. The pig farm, where the animals were maintained is located at $25^{\circ} 41^{\prime} 21^{\prime \prime} \mathrm{N}$ latitude and $91^{\circ} 55^{\prime} 25^{\prime \prime} \mathrm{E}$ longitude at an altitude of $1010 \mathrm{msl}$. The agro climatic zone classified for the place is within the subtropical hill agro ecological zone. The maximum and minimum temperature normally ranges from 20.9 to $27.4^{\circ} \mathrm{C}$ and from 6.7 to $18.1^{\circ} \mathrm{C}$, respectively. The mean annual rainfall was $2399.8 \mathrm{~mm}$ with relative humidity between 85 percent and 59 percent. Fifteen weanling pigs 87.50 percent Hampshire (Hampshire X Meghalaya local) weaned at 60 days of age, apparently healthy with uniform body weight were selected for the experiment and were randomly allocated into 3 treatment groups viz. Group A, B and C with 5 in each group. The supplementation was done as follows: Group A=100ppm Zn; NRC (1998) recommended which was considered as control, Group B $=200 \mathrm{ppm} \mathrm{Zn}$ and Group $\mathrm{C}=300 \mathrm{ppm} \mathrm{Zn}$. The experimental animals were kept under intensive system of rearing as per standard farm managemental practices. The experiment was conducted for the period of 4 months ( 2 to 6 months of age).

Body weights of the experimental pig were recorded from two (2) months of age at fortnightly interval till attainment of six (6) months of age before feeding between 8-10 AM. Blood samples of the individual experimental pig were collected from 2 months of age at fortnightly interval till attainment of 6 months of age from the anterior vena cava. For estimation of serum zinc concentration the serum 


\section{International Journal of Science and Research (IJSR) \\ ISSN (Online): 2319-7064}

Index Copernicus Value (2015): 78.96 | Impact Factor (2015): 6.391

samples were processed as per the method described by Fick, et al. (1979) and estimated with the help of Atomic Absorption Spectrophotometer (AAS), GBC 932AA. The serum amylase activity and glucose concentration were estimated using the Rotor- Comprehensive Diagnostic Profile for Veterinary use in "Vetscan" manufactured by Abaxis. Serum insulin was estimated by using ELISA (E nzyme- Linked- Immunosorbant Assay) kits supplied by RayBio. The significant differences of values for different parameters studied were assessed by the test of analysis of variance, while the critical difference test was performed to evaluate the significant difference among the groups. All the above calculations were carried out using SPSS softwere version 11.5.

\section{Result and Discussion}

As presented in Fig. 1 the significant highest $(\mathrm{P}<0.01) \mathrm{BWG}$ at 6 months of age was recorded in group $\mathrm{C}(54.00 \pm 0.500$ $\mathrm{kg})$ followed by B $(51.20 \pm 1.158 \mathrm{~kg})$ and lowest in A (45.00 $\pm 0.873 \mathrm{~kg})$. As the dietary supplemental dose of $\mathrm{Zn}$ increased, the BWG also recorded higher values accordingly. This finding was in agreement with the reports of Hill et al, 2001; Heugtat et al. (2001); Xilong, el al. (2006); Deka et al. (2013). Serum zinc concentration increases along with advancement of age irrespective of the treatment groups (Table.1). Many earlier workers has reported that supplementation of zinc in the diet during the growing age results steady rise in serum zinc concentration with advancement of age (Harlikar et.al., 2000; Kalita et.al., 2006; Borah, 2009; Saikia, 2010).

The initial serum amylase activities (Mean \pm SE) at 2 month of age in A,B and C groups were recorded as $1390.00 \pm$ $15.21,1397.00 \pm 10.81$ and $1423.00 \pm 17.76, \mathrm{U} / \mathrm{L}$ respectively and at 6 month of age in A, B and C group were recorded as $1499.00 \pm 17.69,2274.00 \pm 114.59$ and 2848.00 $\pm 81.84 \mathrm{U} / \mathrm{L}$ respectively. Significantly $(\mathrm{P}<0.01)$ higher serum amylase activities were found in group $\mathrm{C}$ than that of the control and the lowest activity was in A group (control). The primary source of amylase is the parotid salivary gland and centroacinar cells of the pancreatic gland. This enzyme is responsible for hydrolyzing the polymer of glucose unit at position $1,6, \alpha$ - linkage resulting in liberation of maltose and glucose. In the present study, it was observed that serum amylase activity increased with the advancement of age. This might be due to the fact that, with advancement of age there was increased in the intake of carbohydrate along with other nutrients which, might stimulated the parotid gland as well as the pancreatic gland to secrete more amylase. Earlier Akuzawa (1992) also observed similar increased trend in serum amylase activities along with advancement of age in pigs.

Present study also showed that, the serum amylase activity increased progressively as the concentration of supplemental zinc increases. There is evidence in support of this finding that zinc has a stimulatory affect of Gustin and carbonic anhydrase enzymes (Berger, 2002) and these enzymes are required for development of the taste buds which may stimulate appetite and enhance the feed consumption (Henkin and Bradley, 1970; Szabb et al.,2004) so might have stimulatory affect on synthesis and secretion of salivary amylase. Zinc also might have a stimulatory affect on pancheatic amylase secretion which has resulted in the net increased in serum amylase activities. Szabb et al.(2004) also reported that supplementation of zinc at higher concentration than that of the NRC (1998) recommendation resulted increased in activities of amylase along with other enzymes namely, lipase, trypsinase and total protease in the pancreatic homogenate and small intestinal content. (Hedemann et al., 2006) also found that zinc supplementation at the rate of $2500 \mathrm{ppm}$ increased in activities of amylase, carboxypeptidase A, chymotrypsin, trypsin and lipase in pigs.

The serum glucose concentration of the different treatment groups at fortnight interval from 2 month to 6 month of age were presented in Table 1. The initial serum glucose concentration (Mean $\pm \mathrm{SE}$ ) at the 2 month of age was recorded as $79.98 \pm 4.55,75.88 \pm 2.52$ and $79.91 \pm 1.89$ $\mathrm{mg} / 100 \mathrm{ml}$ and the final serum glucose concentration at 6 month of age in A, B and C group was recorded as $87.90 \pm$ $4.43,84.62 \pm 2.61$ and $81.82 \pm 2.65 \mathrm{mg} / 100 \mathrm{ml}$ respectively. The highest serum glucose concentration was attained in group A whereas the lowest concentration was in group C. Table 1 showed an increasing in serum glucose concentration within the group in first fortnight from 2 months to 2.5 months of age then, a definite decreasing trend from 3 to 6 months of age was recorded

The serum glucose ranged between $80-120 \mathrm{mg} / 100 \mathrm{ml}$ (Dukes, 1996) whereas, Eveleth and Eveleth (1935) reported the normal level of blood glucose concentration of pig as 65 $95 \mathrm{mg} / 100 \mathrm{ml}$ of blood. The Present finding revealed that the serum glucose concentration ranged between 65.74 -100.76 $\mathrm{mg} / 100 \mathrm{ml}$. There was an increase in the serum glucose concentration within the groups from 2 month to 2.5 months of age then; a definite declining trend from 3 months to 6 month of age was recorded. The initial increasing trend of serum glucose concentration within the groups in first fortnight from 2 month to 2.5 months of age may be attributed to the stimulation of the carbohydrate metabolism due to supplementation of dietary Zinc. There were various zinc dependent enzymes related to carbohydrate metabolism such as lactase, maltase and sucrase of small intestine (Hedemann et al., 2006). Azizzadeh et al., (2005) also reported that zinc supplementation in the diet reduces the serum glucose concentration.

The initial serum insulin concentration (Mean $\pm \mathrm{SE}$ ) at 2 month of age in $\mathrm{A}, \mathrm{B}$ and $\mathrm{C}$ groups were recorded as $0.83 \pm$ $0.019,0.82 \pm 0.018$ and $0.81 \pm 0.013 \mu \mathrm{IU} / \mathrm{ml}$ respectively and at 6 month of age in $\mathrm{A}, \mathrm{B}$ and $\mathrm{C}$ group were recorded as 1.12 $\pm 0.015,1.51 \pm 0.047$ and $1.77 \pm 0.019 \mu \mathrm{IU} / \mathrm{ml}$ respectively. Significantly $(\mathrm{P}<0.01)$ higher serum insulin concentration was found in group $\mathrm{C}$ and the lowest was in group $\mathrm{A}$ (control).This might be due to the fact that insulin molecules are assembled in a hexamer and the zinc ion holding it together (Derewenda et al., 1989) subsequently zinc play a very important role in synthesis and secretion of insulin in the beta cell of the pancreas (Huang and Arvan,1995). Zinc stimulates insulin - signaling pathway hence, zinc has insulin like effect on cells (Xiao and Neil, 2001) therefore, zinc dependent insulin secretion promotes the transport of 


\section{International Journal of Science and Research (IJSR) \\ ISSN (Online): 2319-7064}

Index Copernicus Value (2015): 78.96 | Impact Factor (2015): 6.391

extracellular glucose into the different cells of the body there by lowering the blood.

\section{Conclusion}

Higher dietary supplemental zinc (200ppm:20ppm; 300ppm:30ppm) than that of the NRC (1998) recommendation from 2 to 6 months of age increased the serum zinc concentration which stimulates to increase the amylase activity. More in amylase activities will in turn increase carbohydrate digestion and make more glucose available. Since zinc has a profound effect in elevating the insulin concentration by stimulating insulin signaling pathway, ultimately increased use of the available glucose for cellular activities and reduces the serum glucose concentration which might be a major cause of growth promoting affect of zinc. Further it concludes that zinc regulates the Amylase- Glucose- insulin interrelionship for enhancement of growth performances in weanling pig.

\section{Acknowledgement}

The authors duly acknowledge ICAR sponsored projects AICRP on "Improvement of Feed Resources and Nutrient Utilization in Raising Animal Production."and ICAR Research Complex for North Eastern Hill Region, Umiam, Barapani, Meghalaya for extending help to conduct the experiment.

\section{References}

[1] Akuzawa, M.; Morijono, M.; Sudo, K.; Yasuda, N. and Okamota, D..E., 1992: Serum total amylase activity and its isoenzymes fractions in newborn pig with relation to growth and iron dextrin treatament. J. Vet. Med. Sci. 54, 1151-1155.

[2] Azizzadeh, M.; Mohri, M. and Seifi, H.A., 2005: Effect of oral zinc supplementation on hematology, serum biochemistry, performance, and health in neonatal dairy calves. Comp. Clini. Path.14, 67-71.

[3] Berger, L.L., 2002: Zinc: nutritional and pharmacological roles. Salt Institute. Salt and Trace Minerals Newsletter, Winter, 34, 3.

[4] Borah, S., 2009: Role of zinc on growth, reproduction and immune system in pigs. Ph.D. Thesis, Assam Agricultural University, Guwahati, Assam.

[5] Carlson, M.S. and Boren, C.A., 2001: Mineral requirements for growing swine http:// extention.missouri.edu/publication/display pub.aspx? $=$ $=2322$.

[6] Chauhan, R.S.; Agarwal, D.K. and Tyagi, R.P.S., 2006: Examination of blood and serum of biochemical attributes. In: Textbook of veterinary clinical and laboratory diagnosis. $2^{\text {nd }}$ Edn. Pp: 193-206.

[7] Deka, I.; Sarmah,B.C.; Goswami,J.; Kumar, S.; Sarma, D.N.; Dutta, D.J. and Kalita, D., 2014: Effect of supplementation of zinc :copper with or without phytase on body weight gain, average daily weight gain and feed conversion efficiency of weanling piglet. The IIOAB J. 4,15-19

[8] Derewenda, V.; Derewenda, Z.; Dodson, G.G.; Hubbard, R.E. and Korber, F., 1989: Molecular structure of insulin - the insulin monomer and its essembly. Br. Med. Bull., 45, 4-18.

[9] Dukes, R.H., 1996: The Physiology of Domestic Animals. Melvin J Swenson and William, 0. Reeche (eds.). Comstock Publishing Associates, Ithaca and London. 42.

[10] Eveleth, D.F. and Eveleth, E.L., 1935: J. Biol-Chem. (c.r Clinical Biochemistry of Domestic Animals. 2nd edn., Vol. I, Kaneko, J.J. and Cornelius, E.C. (eds.), Academic Press, New York).

[11] Fick, K.R.; McDowel, L.R.; Miles, P.H.; Wilkinson, N.S.; Funk, J.D. and Conrad, J.H., 1979: Methods of mineral analysis for plant and animal tissues, $2^{\text {nd }}$ edn., Univ. Florida, Gainesville.

[12] Harlikar, M.N.; Tavelkar, B.A.; Deshmukh, B.T.; Nagvekar, A.S. and Ingole, S.D., 2000: Trace elements profile during growth in crossbred calves and heifers. Indian J. Anim. Sci., 70, 1147-1149.

[13] Hedemann, M.S.; Jensen, B.B. and Poulsen, H.D., 2006: Influence of dietary zinc and copper on digestive enzyme activity and intestinal morphology in weaned pigs. J. Anim. Sci., 84, 3310-3320.

[14] Henkin, R.I. and Bradley, D.F., 1970: Hypogeusia corrected by $\mathrm{Ni}^{++}$and $\mathrm{Zn}^{++}$. Life Sci., 9, 701-709.

[15]Heugnten, E.V.; Spears, J.W.; Kegley, E.B.; Ward, J.D. and Qureshi, M.A., 2003: Effect of organic forms of zinc on growth performance, tissue zinc distribution and immune response of weanling pigs. J. Anim. Sci., 81, 2063-2071.

[16] Hill, G.M.; Mahan, D.C.; Carter, S.D.; Cromwell, G.L.; Ewan, R.C.; Harrold, R.L.; Lewis, A.J.; Miller, P.S.; Shurson, G.C. and Veum, T.L., 2001: Effect of pharmacological concentration of zinc oxide with or without the inclusion of an antibacterial agent in nursery pig performance. J. Anim. Sci., 79, 934-941.

[17]Huang X.F. and Arvan P., 1995: Intracellular transport of proinsulin in pancreatic $\beta$-cellsstructural maturation probed by disulfide accessibility. J. Biol. Chem. 270, 20417-20423

[18] Kalita, D.J.; Sarma, B.C.; Bhattacharya, B.N. and Mili, D.C., 2006: Serum mineral profile of Assam local goats of hill zone during different physiological stages. Indian J. Anim. Res., 40, 93-94.

[19] Kumar, N.; Verma, R.P.; Singh, L.P.; Varshney, V.P. and Dass, R.S., 2006: Effect of different levels and sources of zinc supplementation on quantitative and qualitative semen attributes and serum testosterone level in crossbred cattle (Bos indicus x Bos Taurus) bulls. Reprod. Nutr. Dev., 46, 663-675.

[20] Martinez, M. M.; Hill, M. G.; Link E. J.; Raney E. N.; Tempelman, J. R. and Ernst, W. 2005: Pharmacological zinc and phytase supplementation enhance metalothionine mRNA abundance and protein concentration in newly weaned pigs. J. Nutr., 134, 538544.

[21]Pallauf, J.,2005: The importance of trace elements in animal nutrition, EMFEMA symposium, Brussels,; inst. of Animal Nutrition and Nutritional Physiology, Justus KLiebig Univ. Gieessen, Germeny.

[22] Saikia, A.,2010: Effect of supplemental zinc and phytase on the performance of growing and finishing crossbred pigs. M.V.Sc. Thesis, Assam Agricultural University, Guwahati, Assam. 


\section{International Journal of Science and Research (IJSR) \\ ISSN (Online): 2319-7064 \\ Index Copernicus Value (2015): 78.96 | Impact Factor (2015): 6.391}

[23] Scannapieco, F.A.; Torres, G. and Levine, M.J., 1993: Salivary alpha amylase: role in dental plaque and caries formation. Crit. Rev. Oral. Biol. Med., 3, 301-307.

[24] Szabb, J.; Mihaly, H.; Geza, B., and Emmakosa, B., 2004: Large doses of zinc oxide increases activity of hydrolysis in rat. J.Nutr. Biochem., 15, 206-209.

[25] Xiao-han Tang and Neil, F. Shay, 2001: Zinc has an insulin like effect as glucose transport mediated by phosphoinositol-3-kinase and Akt in 3T3-L1 fibroblasts and Adipocytes. J. Nutrn., 131, 1414-1420.
[26] Xilong, L.; Jingdong, Y.; Defa, L.; Xingjie, C.; Jianjun, Z.; Xuan, Z., 2006: Dietary supplementation with zinc oxide increases IGF-I and IGF-I receptor gene expression in the small intestine of weanling piglets. $J$. Nutr. 136, 1786-1791.

[27] Yousef, M.I.; El Hendy, H.A.; El-Demerdash, F.M. and Elagamy, E.L., 2002: Diatary Zinc deficiency inducedchanges in the activity of enzymes and the levels of free radicles ,lipids, protein electrophoretic behavior in growing rats. $w w w$.Scientific Direct.Com

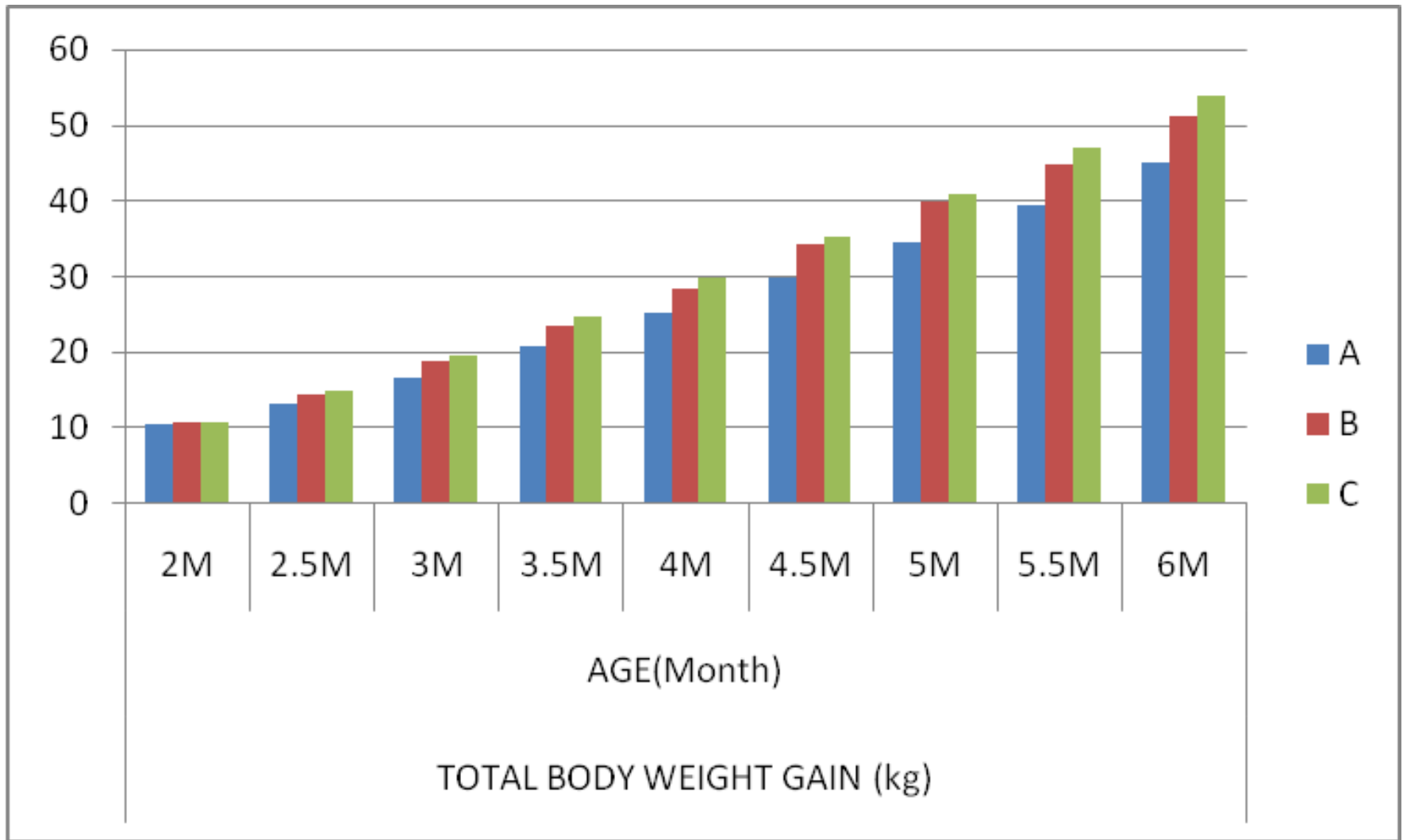

Figure 1: Body weight gain $(\mathrm{kg})$ in different treatment groups from 2 to 6 months of age in weanling pig.

Table 1: Serum zinc, amylase, glucose and insulin (Mean \pm SE) in different treatment groups from 2 to 6 months of age in weanling pig

\begin{tabular}{|c|c|c|c|c|c|c|c|c|c|c|c|c|}
\hline \multirow{2}{*}{$\begin{array}{c}\text { Age } \\
\text { (month) }\end{array}$} & \multicolumn{3}{|c|}{ Serum Zinc(ppm) } & \multicolumn{3}{|c|}{ Serum Amylase(U/L) } & \multicolumn{3}{|c|}{ Serum Glucose $(\mathrm{mg} / 100 \mathrm{ml})$} & \multicolumn{3}{|c|}{ Serum Insulin $(\mu \mathrm{IU} / \mathrm{ml})$} \\
\hline & A & B & $\mathrm{C}$ & A & B & C & A & B & $\mathrm{C}$ & A & B & $\mathrm{C}$ \\
\hline 2 & $\begin{array}{c}0.787^{\mathrm{a}} \\
\pm 0.019\end{array}$ & $\begin{array}{c}0.779^{\mathrm{a}} \\
\pm 0.014\end{array}$ & $\begin{array}{c}0.759^{\mathrm{a}} \\
\pm 0.017\end{array}$ & $\begin{array}{c}1390^{\mathrm{a}} \\
\pm 15.21\end{array}$ & $\begin{array}{c}1397^{\mathrm{a}} \\
\pm 10.81\end{array}$ & $\begin{array}{c}1423^{\mathrm{a}} \\
\pm 17.76\end{array}$ & $\begin{array}{l}79.98^{\mathrm{a}} \\
\pm 4.55\end{array}$ & $\begin{array}{l}75.88 \mathrm{a} \\
\pm 2.52\end{array}$ & $\begin{array}{l}79.91^{\mathrm{a}} \\
\pm 1.89\end{array}$ & $\begin{array}{c}0.83^{\mathrm{a}} \\
\pm 0.019\end{array}$ & $\begin{array}{c}0.82^{\mathrm{a}} \\
\pm 0.018\end{array}$ & $\begin{array}{c}0.81^{\mathrm{a}} \\
\pm 0.013\end{array}$ \\
\hline 2.5 & $\begin{array}{c}0.871^{\mathrm{a}} \\
\pm 0.015\end{array}$ & $\begin{array}{c}0.972^{b} \\
\pm 0.076\end{array}$ & $\begin{array}{l}1.055^{\mathrm{c}} \\
\pm 0.029\end{array}$ & $\begin{array}{c}1396^{\mathrm{a}} \\
\pm 18.61\end{array}$ & $\begin{array}{l}1461^{\mathrm{a}} \\
\pm 1.83\end{array}$ & $\begin{array}{c}1513^{\mathrm{a}} \\
\pm 53.48\end{array}$ & $\begin{array}{c}100.76^{\mathrm{a}} \\
\pm 4.44\end{array}$ & $\begin{array}{c}99.37 \mathrm{a} \\
\pm 1.81\end{array}$ & $\begin{array}{l}98.36^{\mathrm{a}} \\
\pm 2.12\end{array}$ & $\begin{array}{c}0.85^{\mathrm{a}} \\
\pm 0.014\end{array}$ & $\begin{array}{c}0.88^{\mathrm{a}} \\
\pm 0.032\end{array}$ & $\begin{array}{c}0.85^{\mathrm{a}} \\
\pm 0.037\end{array}$ \\
\hline 3 & $\begin{array}{c}0.913^{\mathrm{a}} \\
\pm 0.013\end{array}$ & $\begin{array}{l}1.013^{b} \\
\pm 0.022\end{array}$ & $\begin{array}{l}1.260^{\mathrm{c}} \\
\pm 0.031\end{array}$ & $\begin{array}{c}1399^{\mathrm{a}} \\
\pm 14.29\end{array}$ & $\begin{array}{r}1514^{\mathrm{a}} \\
\pm 28.77\end{array}$ & $\begin{array}{c}1784^{b} \\
\pm 61.11\end{array}$ & $\begin{array}{l}99.74^{\mathrm{a}} \\
\pm 2.06\end{array}$ & $\begin{array}{l}97.01^{\mathrm{a}} \\
\pm 2.52\end{array}$ & $\begin{array}{l}94.51^{\mathrm{a}} \\
\pm 1.48\end{array}$ & $\begin{array}{c}0.93^{\mathrm{a}} \\
\pm 0.034\end{array}$ & $\begin{array}{c}0.99^{\mathrm{a}} \\
\pm 0.025\end{array}$ & $\begin{array}{c}1.02^{\mathrm{a}} \\
\pm 0.018\end{array}$ \\
\hline 3.5 & $\begin{array}{c}0.946^{\mathrm{a}} \\
\pm 0.014\end{array}$ & $\begin{array}{l}1.094^{b} \\
\pm 0.021\end{array}$ & $\begin{array}{l}1.306^{\mathrm{cd}} \\
\pm 0.027\end{array}$ & $\begin{array}{c}1407^{\mathrm{a}} \\
\pm 36.32\end{array}$ & $\begin{array}{c}1848^{b} \\
\pm 36.52\end{array}$ & $\begin{array}{c}2049^{b} \\
\pm 132.90\end{array}$ & $\begin{array}{c}95.36^{\mathrm{a}} \\
\pm 0.73\end{array}$ & $\begin{array}{r}93.36^{\mathrm{a}} \\
\pm 1.69\end{array}$ & $\begin{array}{l}90.49^{\mathrm{a}} \\
\pm 2.59\end{array}$ & $\begin{array}{c}0.98^{\mathrm{a}} \\
\pm 0.020\end{array}$ & $\begin{array}{c}1.12^{\mathrm{a}} \\
\pm 0.016\end{array}$ & $\begin{array}{c}1.52 \\
\pm 0.016\end{array}$ \\
\hline 4 & $\begin{array}{c}0.930^{\mathrm{a}} \\
\pm 0.020\end{array}$ & $\begin{array}{l}1.258_{\mathrm{b}} \\
\pm 0.038\end{array}$ & $\begin{array}{l}1.394^{\mathrm{c}} \\
\pm 0.020\end{array}$ & $\begin{array}{c}1412^{\mathrm{a}} \\
\pm 40.00\end{array}$ & $\begin{array}{c}2016^{\mathrm{b}} \\
\pm 54.52\end{array}$ & $\begin{array}{c}2217^{\mathrm{b}} \\
\pm 84.91\end{array}$ & $\begin{array}{l}93.90^{\mathrm{a}} \\
\pm 2.47\end{array}$ & $\begin{array}{l}93.47^{\mathrm{a}} \\
\pm 3.27\end{array}$ & $\begin{array}{l}89.57^{b} \\
\pm 2.26\end{array}$ & $\begin{array}{c}0.96^{\mathrm{a}} \\
\pm 0.038\end{array}$ & $\begin{array}{c}1.23^{\mathrm{b}} \\
\pm 0.010\end{array}$ & $\begin{array}{c}1.59^{\mathrm{c}} \\
\pm 0.031\end{array}$ \\
\hline 4.5 & $\begin{array}{c}0.975^{\mathrm{a}} \\
\pm 0.014\end{array}$ & $\begin{array}{l}1.312^{b} \\
\pm 0.015\end{array}$ & $\begin{array}{l}1.557^{\mathrm{C}} \\
\pm 0.017\end{array}$ & $\begin{array}{r}1438^{\mathrm{a}} \\
\pm 27.60\end{array}$ & $\begin{array}{c}2143^{\mathrm{b}} \\
\pm 40.94\end{array}$ & $\begin{array}{c}2384^{\mathrm{C}} \\
\pm 52.64\end{array}$ & $\begin{array}{r}94.31^{\mathrm{a}} \\
\pm 14.97\end{array}$ & $\begin{array}{l}88.74^{\mathrm{a}} \\
\pm 3.78\end{array}$ & $\begin{array}{l}87.81^{\mathrm{a}} \\
\pm 2.10\end{array}$ & $\begin{array}{c}0.98^{\mathrm{a}} \\
\pm 0.015\end{array}$ & $\begin{array}{c}1.33^{\mathrm{b}} \\
\pm 0.014\end{array}$ & $\begin{array}{c}1.63^{\mathrm{c}} \\
\pm 0.013\end{array}$ \\
\hline 5 & $\begin{array}{l}0.958^{\mathrm{a}} \\
\pm 0.097\end{array}$ & $\begin{array}{l}1.332^{\mathrm{b}} \\
\pm 0.023\end{array}$ & $\begin{array}{c}1.717^{\mathrm{c}} \\
\pm 0.028\end{array}$ & $\begin{array}{c}1456^{\mathrm{a}} \\
\pm 25.00\end{array}$ & $\begin{array}{r}2198^{\mathrm{b}} \\
\pm 96.37\end{array}$ & $\begin{array}{c}2512^{\mathrm{c}} \\
\pm 51.12\end{array}$ & $\begin{array}{l}90.37^{\mathrm{a}} \\
\pm 2.89\end{array}$ & $\begin{array}{l}87.47^{\mathrm{a}} \\
\pm 2.19\end{array}$ & $\begin{array}{l}84.42^{\mathrm{a}} \\
\pm 2.94\end{array}$ & $\begin{array}{c}1.02^{\mathrm{a}} \\
\pm 0.023\end{array}$ & $\begin{array}{c}1.45^{\mathrm{b}} \\
\pm 0.052\end{array}$ & $\begin{array}{c}1.79^{\mathrm{c}} \\
\pm 0.027\end{array}$ \\
\hline 5.5 & $\begin{array}{r}1.190^{\mathrm{a}} \\
\pm 0.015 \\
\end{array}$ & $\begin{array}{r}1.389^{b} \\
\pm 0.027\end{array}$ & $\begin{array}{l}1.801^{\mathrm{c}} \\
\pm 0.028 \\
\end{array}$ & $\begin{array}{r}1478^{\mathrm{a}} \\
\pm 23.74 \\
\end{array}$ & $\begin{array}{r}2362^{b} \\
\pm 54.26 \\
\end{array}$ & $\begin{array}{r}2693^{\mathrm{c}} \\
\pm 29.27 \\
\end{array}$ & $\begin{array}{l}88.29^{\mathrm{a}} \\
\pm 4.26 \\
\end{array}$ & $\begin{array}{l}86.27^{\mathrm{a}} \\
\pm 6.83 \\
\end{array}$ & $\begin{array}{l}83.42^{\mathrm{a}} \\
\pm 2.08 \\
\end{array}$ & $\begin{array}{r}1.11^{\mathrm{a}} \\
\pm 0.023 \\
\end{array}$ & $\begin{array}{c}1.50^{\mathrm{b}} \\
\pm 0.015 \\
\end{array}$ & $\begin{array}{c}1.69^{\mathrm{c}} \\
\pm 0.046 \\
\end{array}$ \\
\hline 6 & $\begin{array}{c}1.154^{\mathrm{a}} \\
\pm 0.018\end{array}$ & $\begin{array}{l}1.400^{b} \\
\pm 0.025\end{array}$ & $\begin{array}{c}1.849^{\mathrm{c}} \\
\pm 0.012\end{array}$ & $\begin{array}{c}1499^{\mathrm{a}} \\
\pm 17.69\end{array}$ & $\begin{array}{c}2274^{b} \\
\pm 114.59\end{array}$ & $\begin{array}{c}2848^{\mathrm{c}} \\
\pm 81.84\end{array}$ & $\begin{array}{l}87.90^{\mathrm{a}} \\
\pm 4.43\end{array}$ & $\begin{array}{l}84.62^{b} \\
\pm 2.61\end{array}$ & $\begin{array}{l}81.82^{b} \\
\pm 2.65\end{array}$ & $\begin{array}{c}1.12^{\mathrm{a}} \\
\pm 0.015\end{array}$ & $\begin{array}{c}1.51^{\mathrm{b}} \\
\pm 0.047\end{array}$ & $\begin{array}{c}1.77^{\mathrm{c}} \\
\pm 0.019\end{array}$ \\
\hline
\end{tabular}

Mean bearing similar superscript in a row for each parameter do not differ significantly. 